\title{
IMPLEMENTASI KOMUNIKASI PEMASARAN PADA PRODUK HASIL OLAHAN LIMBAH BOTOL PLASTIK DI KOTA MALANG
}

\author{
Yayuk Sri Rahayu \\ Jurusan Manajemen Fakultas Ekonomi UIN Maulana Malik Ibrahim Malang \\ Jl. Gajayana 50 Malang \\ E-mail: yayukfeuinmalang@gmail.com
}

\begin{abstract}
Marketing communication has an important role in new product marketing process to inform dan promote the existing products. This research was focused and aimed to identify the implementation of marketing communication on recycle product from plastic bottles trashes at Malang. The research is descriptive qualitative and data was collected by quesionaire and observation. The result shows that producers of recycle product plastic bottles trashes have already implemented four marketing communication programs consist of advertising, sales promotion, publicity, dan personal selling. However, they have not implement direct marketing yet because lack of human resuorces.
\end{abstract}

Key Words: Marketing communication, promotion, plastic bottles trashes

Sampah merupakan permasalahan sosial yang tidak kunjung selesai walaupun telah banyak program dilakukan untuk mengatasi dan mengurangi jumlahnya. Salah satu permasalahan terkait dengan sampah adalah solusi untuk mengatasi sampah plastik. Pemakaian produk berbahan plastik yang semakin meluas semakin memperparah kondisi. Hampir semua barang-barang yang ada di sekeliling kita tak lepas dari bahan plastik. Mulai dari mainan anak, alat kantor, alat rumah tangga sampai benda-benda elektronik berbungkus plastik. Plastik memang lebih praktis ketimbang bahan tradisional yang membutuhkan perawatan khusus. Tak hanya itu, plastik juga relatif murah dan mudah bercampur dengan aneka bahan pewarna. Namun dibalik kepraktisan itu ada bahaya mengintip dalam pemakaian plastik. Setidaknya ada dua bahaya plastik. Pertama, plastik akan menjadi sampah yang sulit terurai karena termasuk produk non-biodegrable. Plastik baru bisa terurai setelah 1.000 tahun. Bandingkan dengan limbah kertas yang membutuhkan waktu sebulan untuk terurai. Kedua, plastik mengandung bahan kimia yang berbahaya yakni Bisphenol A (BPA) yang bias merangsang pertumbuhan sel kanker serta memperbesar resiko keguguran pada ibu hamil. 
Di Negara berkembang seperti Cina kini sedang gencar melakukan kampanye white pollution, yaitu kampanye melawan polusi limbah plastik. Mulai Juni 2008, salah satu kegiatan yang dilakukannnya yaitu seluruh department store dan toko-toko di Cina dilarang memberikan kantong plastik gratis kepada konsumen, sebagai gantinya konsumen dianjurkan untuk menggunakan karung kain atau keranjang. Selain Cina, Negara lain yang mulai melarang penggunaan plastik adalah Australia. Di Indonesia sendiri beberapa perusahaan telah ikut berpartisipasi dalam rangka penanganan sampah plastik seperti program ReuseReduce-Recycle atau 3R dapat diterapkan dalam keseharian masyarakat sebagai pendukung gerakan penghijauan. Reuse, kita dapat menggunakan kembali wadah atau tempat kemasan yang masih dapat digunakan. Reduce, kita harus mengurangi pemakaian barang-barang yang sifatnya anorganik. Recycle, mengolah kembali barang-barang ataupun sampah menjadi suatu bentuk yang memiliki daya guna.

Pengolahan limbah plastik khususnya botol plastik menjadi berbagai produk yang bernilai ekonomis telah mulai dilakukan. Salah satunya adalah program pendampingan kemitraan pengolahan limbah botol plastik menjadi produk yang bernilai ekonomis di Desa Girimoyo Kecamatan Karangploso Kabupaten Malang yang dilakukan oleh tim peneliti dari Fakultas Ekonomi UIN Maulana Malik Ibrahim Malang. Program tersebut telah menghasilkan kelompok masyarakat yang mau dan mampu mengolah limbah botol plastik yang terdiri dari petugas kebersihan, keluarganya, dan elemen masyarakat lain dengan jumlah lebih dari 30 orang (Hidayah, 2011).

Produk hasil olahan limbah botol plastik antara lain berupa aksesoris (bros, kalung, gelang, anting, peniti jilbab, bando), sabuk, wadah-wadah cantik, dan lain sebagainya. Namun keberlangsungan kegiatan tersebut mengalami kendala terutama pemasaran produk yang telah dihasilkan. Masyarakat yang mengolah dan memproduksi, mengalami kesulitan untuk memasarkan produknya karena produk hasil olahan limbah botol plastik ini tergolong produk baru yang belum diketahui oleh masyarakat. Kesulitan yang lain adalah mereka belum mengetahui dan memahami cara memasarkan produk sehingga penjualan produk masih sangat terbatas. 
Jika ditinjau dari siklus hidup produk (product life cycle), produk hasil olahan limbah botol plastik baru memasuki tahap pertama yaitu tahap perkenalan. Tahapan ini ditandai dengan penjualan yang masih rendah, volume pasar berkembang lambat, persaingan relatif kecil, tingkat kegagalan yang cukup tinggi, biaya produksi dan pemasaran sangat tinggi serta distribusi produk masih sangat terbatas (Tjiptono, 2006: 275). Pada tahap ini, yang harus dilakukan adalah mengkomunikasikan dan mempromosikan keberadaan produk tersebut kepada pasar. Promosi yang dilakukan pada tahap ini difokuskan pada usaha membangun permintaan awal (primary demand). Produk baru biasanya juga menimbulkan masalah distribusi karena seringkali retailer atau pengecer tidak bersedia menanggung resiko untuk menjual produk baru. Untuk itu dibutuhkan program komunikasi pemasaran yang intensif.

Komunikasi pemasaran merupakan aktifitas pemasaran yang berusaha menyebarkan informasi, mempengaruhi, membujuk dan atau mengingatkan pasar sasaran akan perusahaan dan produknya agar bersedia menerima, membeli, dan loyal pada produk yang ditawarkan perusahaan tersebut (Tjiptono, 2006:219). Menurut Clow dan Baack (dalam Limakrisna, 2008), komunikasi pemasaran terintegrasi mengkoordinasikan dan mengintegrasikan semua elemen dari komunikasi pemasaran untuk memaksimalkan komunikasi pada konsumen dengan biaya yang relatif rendah. Komunikasi pemasaran terintegrasi merupakan integrasi dari komponennya yang mencakup 8 hal, yaitu misi, target pasar, uang, media, pesan, bauran, pengukuran, dan pemasaran terhubung. Bauran merupakan gabungan dari alat promosi (yang di dalamnya ada iklan, penjualan pribadi, promosi penjualan, relasi publik, dan penjualan langsung). Menurut Kotler (2008, 128) Komunikasi pemasaran terdiri dari lima kegiatan yaitu periklanan (advertising), promosi penjualan (sales promotion), publisitas (publicity), penjualan pribadi (personal selling), dan pemasaran langsung (direct selling). Komunikasi pemasaran mempunyai pengaruh terhadap minat beli konsumen (Iksan, 2011). Bahkan Limakrisna (2008) dalam penelitiannya mengenai komunikasi pemasaran menyatakan bahwa komunikasi pemasaran berpengaruh terhadap loyalitas pelanggan baik secara parsial maupun simultan. 
Oleh karena pentingnya peranan komunikasi pemasaran pada pemasaran produk baru, maka penelitian ini memfokuskan dan bertujuan untuk mengidentifikasi implementasi komunikasi pemasaran pada produk hasil olahan limbah botol plastik di Kota Malang.

\section{Komunikasi Pemasaran}

Pemasaran modern tidak hanya membutuhkan pengembangan produk yang baik, pemberian harga yang menarik, dan membuatnya tersedia bagi pelanggan sasaran tetapi juga harus berkomunikasi harus melakukan komunikasi dengan dengan pelanggannya baik pelanggan lama maupun calon pelanggan potensial (Kotler, 2008:141).

Dalam mempersiapkan komunikasi pemasaran, tugas pertama komunikator adalah mengenali audiens sasaran dan karakteritiknya. Berikutnya, komunikator harus menentukan respon yang dicari, apakah itu kesadaran, pengetahuan, rasa suka, preferensi, atau pembelian. Kemudian harus dibuat suatu pesan yang isi dan strukturnya efektif. Media harus diseleksi baik untuk komunikasi pribadi maupun nonpribadi. Akhirnya, komunikator harus mengumpulkan umpan balik dengan mengamati seberapa besar pasar yang menjadi sadar, mencoba produk, dan puas terhadap prosesnya.

Bauran komunikasi pemasaran (promotion mix) merupakan perpaduan khusus antara periklanan, penjualan pribadi, promosi penjualan, hubungan masyarakat, dan penjualan langsung (Kotler, 2008:111). Berikut penjelasan untuk masing-masing elemen komunikasi pemasaran, yaitu :

\section{Periklanan (advertising)}

Periklanan merupakan segala biaya yang harus dikeluarkan sponsor untuk melakukan presentasi dan promosi nonpribadi dalam bentuk gagasan, barang, atau jasa. Iklan memiliki empat fungsi utama, yaitu menginformasikan seluk beluk produk kepada masyarakat (informative), mempengaruhi masyarakat untuk membeli (persuading), menyegarkan informasi yang telah diterima masyarakat (reminding), dan menciptakan suasana yang menyenangkan sewaktu masyarakat menerima dan mencerna informasi (entertainment). 
Tjiptono $(2006,226)$ menyatakan bahwa iklan mempunyai ciri-ciri sebagai berikut 1. Public presentation, yaitu iklan memungkinkan setiap orang menerima pesan yang sama tentang produk yang diiklankan, 2. Pervasiveness, yaitu pesan iklan yang sama dapat diulang-ulang untuk memantapkan penerimaan informasi, 3. Amplified expresiveness, yaitu iklan mampu mendramatisasi perusahaan dan produknya melalui gambar dan suara untuk menggugah dan mempengaruhi perasaan masayarakat, 4. Impersonality, yaitu iklan tidak bersifat memaksa masyarakat untuk memperhatikan dan menanggapinya karena merupakan komunikasi yang monolog atau satu arah. Periklanan dapat dilakukan dengan iklan cetak, iklan elektronik, film, brosur, poster, selebaran, billboard, spanduk, banner, simbol, dan logo.

\section{Penjualan pribadi (personal selling)}

Penjualan pribadi merupakan presentasi pribadi oleh para wiraniaga perusahaan dalam rangka mensukseskan penjualan dan membangun hubungan dengan pelanggan. Sifat-sifat personal selling, antara lain Personal confrontation, yaitu adanya hubungan yang hidup, langsung, dan interaktif antara dua orang atau lebih, Cultivation, yaitu sifat yang memungkinkan berkembangnya segala macam hubungan mulai dari sekedar jual beli sampai dengan hubungan yang lebih akrab, Response, yaitu situasi yang seolah-olah mengharuskan pelanggan untuk mendengar, memperhatikan, dan menanggapi.

Oleh karena sifat-sifat tersebut metode ini mempunyai kelebihan antara lain operasinya ini lebih fleksibel karena penjual dapat mengamati reaksi pelanggan dan menyesuaikan pendekatannya, meminimalkan usaha yang dirasa tidak perlu, pelanggan yang berminat dapat langsung membeli, dan penjual dapat membina hubungan jangka panjang dengan pembeli. Penjual yang ditugaskan untuk melakukan personal selling harus memenuhi beberapa kritera berikut 1 . Salesmanship, yaitu penjual harus memiliki pengetahuan tentang produk dan menguasai seni menjual seperti cara mendekati pelanggan, memberikan presentasi dan demonstrasi, mengatasi penolakan pelanggan, dan mendorong pembelian, 2. Negotiating, yaitu penjual harus mempunyai kemampuan untuk bernegosiasi 
tentang syarat-syarat penjualan, dan 3. Relationship marketing, yaitu penjual harus tahu cara membina dan memelihara hubungan baik dengan para pelanggan.

Penjualan pribadi dapat dilakukan dengan presentasi penjualan, pertemuan penjualan, progran insentif, contoh/sampel, dan pameran dagang.

\section{Promosi penjualan (sales promotion)}

Promosi penjualan merupakan insentif jangka pendek untuk mendorong pembelian atau penjualan suatu produk atau jasa. Melalui promosi penjualan, perusahaan dapat menarik pelanggan baru, mempengaruhi pelanggannya untuk mencoba produk baru, mendorong pelanggan membeli lebih banyak, menyerang aktifitas promosi pesaing, meningkatkan impulse buying (pembelian tanpa rencana sebelumnya), dan mengupayakan kerjasama yang lebih erat dengan peritel.

Secara keseluruhan, promosi penjualan merupakan taktik komunikasi yang berdampak pada jangka sangat pendek bahkan tidak jarang penjualan meningkat hanya selama kegiatan promosi penjualan berlangsung. Namun demikian, harus diakui bahwa promosi penjualan menghasilkan tanggapan yang lebih cepat daripada iklan. Promosi penjualan dapat dilakukan dengan produk sampel, pameran, demontrasi, kupon, potongan/diskon, hadiah, dan sebagainya.

\section{Hubungan masyarakat (public relation)}

Hubungan masyarakat atau disebut juga publisitas adalah membina hubungan baik dengan publik untuk memperoleh dukungan, membangun citra perusahaan yang baik, dan menangani atau menyingkirkan gosip, cerita, dan peristiwa yang merugikan. Keberhasilan kegiatan publisitas ditentukan oleh pencapaian itikad baik, pengertian, penerimaan, dan dukungan publik. Publikasi dapat dilakukan dengan berbagai cara, antara lain berita, kontak pers, pidato, seminar, laporan tahunan, sponsor, dan sebagainya.

\section{Pemasaran langsung (direct selling)}

Pemasaran langsung merupakan komunikasi langsung dengan pelanggan yang diincar secara khusus untuk memperoleh tanggapan langsung. Melalui 
pemasaran langsung, konsumen dapat memperoleh manfaat berupa penghematan waktu dalam berbelanja. Pemasaran langsung dapat dilakukan dengan surat, telemarketing, e-shopping, television shopping, dan radio. Bergesernya strategi pemasaran dewasa ini dari pemasaran massal ke pemasaran satu-satu yang lebih terarah, ditambah dengan kemajuan teknologi informasi telah menimbulkan dampak yang besar terhadap komunikasi pemasaran. Walaupun masih dianggap penting, media massa mulai kalah populer dengan masuknya begitu banyak media terfokus yang lingkupnya lebih kecil. Perusahaan mulai mengurangi penyiaran luas (broadcasting) dan memperbanyak penyiaran terbatas (narrowcasting) (Kotler, 2008:142). Perusahaan harus bekerja keras dan bersikap proaktif dalam mewujudkan komunikasi yang terbuka, jujur, dan akrab dengan pelanggan dan pengecer.

Pada saat komunikator pemasaran menggunakan media dan bauran promosi yang lebih kaya nemun lebih terfragmentasi dalam menjangkau pasar mereka yang semakin tersebar, mereka harus menghadapi resiko masuk dalam penciptaan komunikasi yang membingungkan konsumen. Untuk mencegah hal ini, semakin banyak perusahaan menggunakan konsep komunikasi pemasaran terpadu (integrated marketing communication) yang menghendaki pengintegrasian semua sumber komunikasi secara lebih hati-hati guna menghasilkan pesan yang lebih jelas dan konsisten kepada pasar sasaran.

\section{METODE}

Penelitian dilakukan di Desa Girimoyo Kecamatan Karangploso Kabupaten Malang. Penentuan lokasi ini didasari oleh di desa tersebut telah terbentuk kelompok masyarakat yang telah mampu mengolah limbah botol plastik menjadi berbagai produk yang bernilai jual. Kelompok masyarakat tersebut merupakan masyarakat binaan tim peneliti dari Fakultas Ekonomi UIN Maulana Malik Ibrahim Malang melalui program Partisipation Action Research (PAR). Kelompok masyarakat ini telah mendapatkan pelatihan dan pendampingan pengolahan limbah botol plastik menjadi produk yang bernilai ekonomis.

Jenis penelitian yang dilakukan adalah penelitian kualitatif deskriptif. Penelitian ini menggunakan data-data empiris dalam mengkaji permasalahan yang 
ada. Hal ini sesuai dengan definisi penelitian kualitatif menurut Masyhuri dan Zainuddin (2008:13) yang menyatakan bahwa penelitian kualitatif adalah penelitian yang pemecahan masalahnya dengan menggunakan data empiris. Dan Iqbal Hasan (2002:98) menyatakan bahwa penelitian kualitatif adalah penelitian yang tidak menggunakan model matematika, model statistik dan ekonometrika atau model-model tertentu lainya. Sedangkan Sugiyono (2008:1) mendefinisikan penelitian kualitatif dengan lebih spesifik yaitu sebagai penelitian yang digunakan untuk meneliti pada kondisi obyek yang alamiah, dimana peneliti adalah sebagai instrument kunci, teknik pengumpulan data dilakukan secara trianggulasi (gabungan), analisis data bersifat induktif, dan hasil penelitian lebih menekankan makna dari pada generalitas.

\section{Metode Analisis Data}

Analisa dari data kualitatif secara khas adalah satu proses yang interaktif dan aktif. Dalam penelitian kualitatif, untuk mencari arti dan pemahamanpemahaman lebih dalam data dibaca berulang-ulang. Menurut Miles dan Huberman (1992:16), terdapat tiga jalur analisis data kualitatif yang dapat digunakan yaitu pertama, reduksi data adalah proses pemilihan, pemusatan perhatian pada penyederhanaan, pengabstrakan dan transformasi data kasar yang muncul dari catatan-catatan tertulis di lapangan. Proses ini berlangsung terus menerus selama penelitian berlangsung, bahkan sebelum data benar-benar terkumpul. Reduksi data tersebut terdiri dari meringkas data, mengkode, menelusur tema, dan membuat gugus-gugus. Reduksi data merupakan bentuk analisis yang menajamkan, menggolongkan, mengarahkan, membuang yang tidak perlu dan mengorganisasi data dengan cara sedemikian rupa sehingga kesimpulan akhir dapat diambil. Reduksi tidak perlu diartikan sebagai kuantifikasi data. Cara reduksi data yaitu seleksi ketat atas data, ringkasan atau uraian singkat, dan menggolongkanya dalam pola yang lebih luas

Kedua, penyajian data adalah kegiatan ketika sekumpulan informasi disusun, sehingga memberi kemungkinan akan adanya penarikan kesimpulan dan pengambilan tindakan. Bentuk penyajian data kualitatif yaitu teks naratif yaitu yang berbentuk catatan lapangan dan matriks, jaringan, grafik dan bagan. Bentuk- 
bentuk ini menggabungkan informasi yang tersusun dalam suatu bentuk yang padu dan mudah diraih, sehingga memudahkan untuk melihat apa yang sedang terjadi, apakah kesimpulan sudah tepat atau sebaliknya melakukan analisis kembali.

Ketiga, penarikan kesimpulan yang dilakukan terus menerus selama berada dilapangan. Dari pengumpulan data, penelitian kualitatif mulai mencari arti benda-benda, mencatat keteraturan pola-pola (dalam catatan teori), penjelasanpenjelasan, konfigurasi-konfigurasi yang mungkin, alur sebab akibat dan proposisi. Kesimpulan-kesimpulan ini ditangani dengan longgar, tetap terbuka dan skeptik, tetapi kesimpulan sudah disediakan dengan belum jelas, namun kemudian meningkat menjadi lebih rinci dan mengakar dengan kokoh. Kesimpulankesimpulan itu juga diverifikasi selama penelitian berlangsung, dengan cara memikir ulang selama penulisan, tinjauan ulang catatan lapangan, tnjauan kembali dan tukar pikiran antar teman sejawat untuk mengembangkan kesepakatan intersubyektif, dan upaya-upaya yang luas untuk menempatkan salinan suatu temuan dalam seperangkat data yang lain

\section{HASIL}

Di Desa Girimoyo Kecamatan Karangploso Kabupaten Malang telah terbentuk kelompok masyarakat yang mau dan mampu mengolah limbah botol plastik yang terdiri dari petugas kebersihan, keluarganya, dan elemen masyarakat lain dengan jumlah lebih dari 30 orang. Kelompok ini diketuai langsung oleh Ibu Dian S yaitu Ibu Sekretaris Desa Girimoyo. Kelompok masyarakat tersebut merupakan masyarakat binaan tim peneliti dari Fakultas Ekonomi UIN Maulana Malik Ibrahim Malang melalui program Partisipation Action Research (PAR). Mereka telah mendapatkan pelatihan dan pendampingan pengolahan limbah botol plastik menjadi produk yang bernilai ekonomis. Kegiatan ini telah menjadi salah satu solusi untuk mengurangi dampak sampah bagi lingkungan terutama plastik yang membutuhkan waktu sangat lama untuk terurai.

Masyarakat mulai mengetahui dan paham akan adanya peluang ekonomi di balik sampah, melalui sedikit sentuhan ketrampilan dan ditambah dengan ketekunan ternyata dapat menaikkan nilai limbah botol dan kemasan plastik yang semula tidak berharga menjadi produk yang banyak dicari. Usaha ini selain 
menambah penghasilan keluarga juga memberikan inspirasi kepada masyarakat yang lain untuk memulai berpartisipasi menangani masalah limbah khususnya plastik dengan baik.

Produk hasil olahan limbah botol plastik adalah produk trash fashion antara lain berupa aksesoris (bros, kalung, gelang, anting, peniti jilbab, bando), sabuk, wadah-wadah cantik, dan lain sebagainya. Animo masyarakat terhadap produk yang dihasilkan dari limbah botol plastik ini (aksesoris dan bentuk lain) cukup baik yang terbukti pada beberapa kegiatan pameran yang diikuti oleh peserta, banyak orang yang mengunjungi stan mereka dan tertarik untuk membeli sehingga banyak produk yang laku seperti anting, bros dan peniti jilbab, kalung, gelang, dan lain-lain. Peserta mulai menikmati hasil dari kegiatan mengolah limbah botol plastik ini yaitu dengan mulai terjualnya produk-produk yang mereka hasilkan sehingga mereka yakin bahwa aktifitas ini banyak memberikan manfaat.

Pendampingan pemasaran yang intensif masih sangat diperlukan karena mereka masih belum benar-benar memahami bagaimana cara memasarkan produk-produk yang telah dihasilkan, termasuk cara mempromosikan, mendisplay, dan mendistribusikan produk mereka. Pendampingan agar kelompok ini mampu berkembang menjadi kelompok usaha yang lebih teroganisir dan professional juga diperlukan sehingga mereka mampu menangkap peluang pendanaan dari lembaga keuangan maupun perbankan.

\section{Program Komunikasi Pemasaran yang Dilakukan}

Produk hasil olahan limbah botol plastik ini tergolong sebagai produk baru yang belum dikenal oleh masyarakat luas. Sehingga memerlukan usaha untuk mengkomunikasikan dan mengenalkan produk secara intensif agar pasar mengetahui dan menyadari keberadaan produk tersebut. Sebuah produk yang tergolong baru harus melaksanakan promosi dengan gencar melalui berbagai progran komunikasi pemasaran.

Beberapa program komunikasi pemasaran yang telah dilakukan oleh para pengrajin produk olahan limbah botol plastik terdiri dari : 


\section{Periklanan}

Pengrajin produk olahan limbah botol plastik belum memanfaatkan periklanan dengan optimal. Hal ini dikarenakan promosi dengan media periklanan membutuhkan biaya yang tidak sedikit sedangkan permodalan dalam bisnis ini masih sangat terbatas. Oleh karena itu, para pengrajin banyak menggunakan metode komunikasi pemasaran yang lain selain periklanan. Namun demikian, rencana untuk mengiklankan produk baik pada media cetak maupun elektronik telah mulai dipikirkan. Untuk sementara periklanan melalui media elektronik dilakukan bersamaan dengan peliputan kegiatan desa dan warga oleh televisi lokal mengingat Desa Girimoyo menjadi salah satu desa percontohan di Kabupaten Malang. Desa Girimoyo menjadi wakil Kabupaten Malang dalam berbagai lomba desa baik tingkat provinsi maupun nasional dan selalu membawa produk-produk unggulan hasil karya warganya. Salah satu produk tersebut adalah berbagai produk hasil olahan limbah botol plastik.

Periklanan yang ada saat ini adalah katalog produk yang berisi ragam produk yang telah dihasilkan. Katalog produk telah banyak diberikan kepada pihak-pihak lain sebagai salah satu alat promosi. Selain katalog juga ada banner yang bisa dibawa di setiap ajang pameran.

\section{Promosi penjualan}

Komunikasi pemasaran dalam bentuk promosi penjualan antara lain dilakukan dengan pemberian contoh produk kepada calon konsumen. Contoh produk diberikan kepada para tamu yang berkunjung ke Desa Girimoyo sebagai oleh-oleh. Hal ini ternyata mempunyai dampak yang sangat bagus karena para tamu tersebut menjadi tertarik untuk membeli produk yang ditawarkan. Setelah mendapatkan contoh produk, mereka menjadi tertarik dan penasaran dengan produk hasil olahan limbah botol plastik yang bagi mereka merupakan produk baru dan belum dikenal luas.

Selain itu, tim dosen pendamping dari Fakultas Ekonomi UIN Maulana Malik Ibrahim Malang juga selalu turut ambil bagian dengan membeli produk tersebut kemudian membagikan secara gratis kepada teman, tetangga, dan saudara 
sebagai salah satu cara untuk mempromosikannya. Promosi penjualan juga dilakukan dengan mengikuti berbagai ajang pameran, antara lain pameran rutin yang diselenggarakan di Balittas Karangploso Kabupaten Malang setiap hari Sabtu dan Minggu, pameran UMKM se-Kabupaten Malang, pameran di Kecamatan Karangploso dan acara-acara tertentu di kampus UIN Maulana Malik Ibrahim Malang.

\section{Publisitas}

Kegiatan publisitas dilakukan secara bersama-sama oleh para pengrajin, perangkat desa, dan tim pendamping. Para pengrajin mengkomunikasikan keberadaan produknya baik pada acara-acara resmi seperti pertemuan PKK, dasawisma, dan posyandu maupun pada acara yang bersifat tidak resmi seperti kunjungan kepada saudara dan famili di desa lain. Pihak Desa Girimoyo (Kepala Desa dan jajarannya) selalu membicarakan keberadaan produk hasil olahan limbah botol plastik pada setiap pertemuan dengan pihak luar. Misalnya, pada setiap pertemuan baik di tingkat desa, kecamatan, bahkan kabupaten dengan harapan akan semakin banyak orang yang mengetahui keberadaan produk tersebut. Sedangkan tim pendamping selalu melaporkan dan menyampaikan keberadaan kelompok dampingannya dengan segala produknya pada acara-acara resmi di kampus seperti melaporkan kepada lembaga pengabdian masyarakat sehingga produk tersebut dapat diikutsertakan pada event-event di lembaga tersebut. Selain itu, tim pendamping juga menyampaikan keberadaan produk tersebut di tempat kediamannya masing-masing, misalnya pada saat pertemuan arisan atau PKK.

\section{Penjualan pribadi}

Penjualan pribadi dilakukan oleh para pengrajin sendiri dan tim pendamping dengan dibantu oleh beberapa mahasiswa. Para pengrajin melakukan penjualan pribadi pada setiap kesempatan pameran, acara desa, dan menitipkan produk-produknya kepada penjual atau toko-toko di pasar baik pasar karangploso dan tempat lain. Sedangkan tim pendamping dengan dibantu oleh mahasiswa melakukan penjualan di kampus dan pusat-pusat pertokoan. Dalam hal ini, 
mahasiswa juga bertindak sebagai marketer atau sales dengan menjual produk tersebut kepada teman-temannya dan berusaha menembus pusat-pusat perbelanjaan untuk membuka pasar baru bagi produk tersebut. Dari usaha tersebut, terdapat beberapa toko yang bersedia dititipi dan menjualkan produk hasil olahan limbah botol plastik. Selain itu, kegiatan ini juga menjadi memberikan kesempatan kepada mahasiswa untuk mengaplikasikan teori yang terkait dengan pemasaran produk sehingga mereka mendapatkan pengalaman bagaimana cara dan kiat menjual produk.

Proses ini bukanlah hal yang mudah dilakukan mengingat produk tersebut merupakan produk baru yang belum dikenal oleh masyarakat luas. Pihak toko atau perantara banyak yang merasa ragu produk tersebut akan laku di pasar sehingga diperlukan ketekunan dan kemampuan khusus untuk meyakinkan mereka agar mau dititipi dan menjualkan produk yang ada. Hal ini merupakan tantangan tersendiri bagi tim pendamping dan mahasiswa dan memberikan pengalaman yang sangat berarti dalam memasarkan produk baru.

\section{Pemasaran langsung}

Pemasaran langsung merupakan pemasaran produk dengan memanfaatkan surat, telepon, atau internet untuk berhubungan langsung dengan konsumen. Pemasaran dengan cara ini belum dilakukan pada produk hasil olahan botol plastik. Saat ini tim pendamping telah mulai menyiapkan untuk melakukan pemasaran on line melalui internet. Namun hal ini memerlukan sumber daya manusia yang menguasai internet dan mampu mengelola promosi on line dengan baik.

\section{PEMBAHASAN}

Beragam program komunikasi pemasaran yang telah diterapkan oleh kelompok masyarakat pengrajin produk hasil olahan limbah botol plastik di Desa Girimoyo diatas perlu ditingkatkan karena masih bersifat dasar dan sangat sederhana. Mengenai periklanan belum dilaksanakan secara maksimal baik melalui media cetak maupun elektronik padahal iklan adalah media yang paling efektif untuk menjangkau masyarakat luas sehingga ke depan harus ada program 
khusus untuk mengiklankan produk yang sudah ada. Penjualan pribadi mengalami kendala masih banyak toko atau retailer yang meragukan produk tersebut dapat terjual sehingga perlu adanya pembekalan dan pelatihan khusus pada orang yang ditugaskan untuk melakukan penjualan pribadi agar mempunyai kemampuan dan keahlian menjual serta meyakinkan pengecer atau retailer bahwa produk ini dapat laku di pasaran.

Kegiatan promosi penjualan perlu untuk terus ditingkatkan dalam rangka mengenalkan produk kepada masyarakat luas sehingga orang menjadi tahu dan berkeinginan untuk membeli produk tersebut. Promosi penjualan dapat dilakukan melalui kegiatan-kegiatan lain yang tidak memerlukan biaya besar atau disesuaikan dengan anggaran yang ada karena kelompok pengrajin ini belum mempunyai modal yang besar bahkan belum terhubung dengan perbankan sebagai sumber modal.

Sedangkan kegiatan publikasi belum diterapkan secara mandiri oleh para pengrajin tetapi masih numpang pada kegiatan-kegiatan desa dan tergantung pada tim pendamping sehingga perlu dilakukan publikasi khusus oleh para pengrajin sendiri. Dan kegiatan pemasaran langsung belum dilaksanakan, oleh karena itu perlu disiapkan sumber daya manusia khusus yang mampu dan menguasai internet untuk mengelola pemasaran on line. Kelompok pengrajin ini dapat bekerjasama dengan pemuda karang taruna dan mahasiswa untuk memulai kegiatan pemasaran on line.

\section{KESIMPULAN DAN SARAN}

\section{Kesimpulan}

Berdasarkan hasil penelitian dan pembahasan maka dapat disimpulkan bahwa para pengrajin produk hasil olahan limbah botol plastik telah mengimplementasi empat program komunikasi pemasaran yaitu periklanan dalam bentuk katalog produk dan banner, promosi penjualan melalui pemberian contoh produk kepada calon konsumen, publisitas dilakukan dengan mengkomunikasikan keberadaan produknya baik pada acara-acara resmi seperti pertemuan PKK, dasawisma, dan posyandu maupun pada acara yang bersifat tidak resmi seperti 
kunjungan kepada saudara dan famili di desa lain, serta penjualan pribadi dengan menjual secara langsung kepada konsumen dan menitipkan produk-produknya kepada toko-toko. Sedangkan pemasaran langsung yang berupa e-marketing belum dilaksanakan karena keterbatasan sumber daya.

\section{Saran}

Berdasarkan kesimpulan di atas maka disarankan kepada para pengrajin produk hasil olahan limbah botol plastik untuk menerapkan progran komunikasi pemasaran dengan lebih intensif agar produk mereka cepat dikenal oleh masyarakat luas. Selain itu mereka juga harus mulai melakukan program pemasaran langsung melalui internet dengan membuat blog atau pemasaran on line lainnya karena saat ini internet sudah menjadi bagian dari kehidupan masyarakat dan merupakan sarana promosi yang efektif. 


\section{DAFTAR RUJUKAN}

Hasan, Iqbal, M. 2002. Pokok-pokok Materi Metoologi Penelitian dan Aplikasinya, Ghalia Indonesia, Jakarta.

Hidayah, Yuniarti SP, Indah Yuliana \& Yayuk Sri Rahayu. 2011. Pendampingan Kemitraan Pengolahan Limbah Botol Plastik Menjadi Produk Bernilai Ekonomis pada Petugas Kebersihan Desa Girimoyo Karangploso Malang. Laporan Penelitian. UIN Maulana Malik Ibrahim Malang.

Iksan, Hafid. 2011.Aktivitas Komunikasi Pemasaran Dan Minat Beli (Studi Korelasional Aktivitas Komunikasi Pemasaran Terhadap Minat Beli Telkomsel Flash Unlimited Corporate di Kalangan Karyawan di PT. Pertamina (Persero) Unit Pemasaran I Medan). Tesis. Universitas Sumatera Utara.

Kotler, Philip \& Gary Amstrong. 2008. Prinsip-Prinsip Pemasaran. Jilid 1. Erlangga. Jakarta. 2008. Prinsip-Prinsip Pemasaran. Jilid 2. Erlangga. Jakarta.

Limakrisna, Nandan. 2008. Pengaruh Komunikasi Pemasaran dan Kerelasian nasabah terhadap Loyalitas Nasabah. Jurnal Ekonomi Bisnis No. 1 Vol. 13, April 2008. Hal 68-79

Masyhuri Dan Zainuddin, M. 2008. Metodologi Penelitian Pendekatan Praktis Dan Aplikatif, PT. Refika Adiama, Bandung.

Miles, MB. And Huberman, AM. 1992. Qualitative Data Analysis: A Sourcebook Of New Methods. SAGE, Beverly Hills, Tjetjep Rohendi, R. (Penerjemah).. Analisis Data Kualitatif: Buku Sumber Tentang MetodeMetode Baru, Univ. Indonesia Press, Jakarta.

Prastowo, Andi. 2010. Menguasai Teknik-Teknik Koleksi Data Penelitian Kualitatif, DIVA Press, Jogakarta.

Sugiyono. 2008. Memahami Penelitian Kualitatif, CV. Alfabeta, Bandung.

Tjiptono, Fandy. 2006. Strategi Pemasaran. Penerbit Andi. Yogyakarta.

Wibowo, Harist Sandhy. 2012. Strategi Komunikasi Pemasaran Website www.bandungreview.com. $\quad$ Vol 11301 No http://jurnal.unpad.ac.id/ejournal/article/view/1801 